\title{
Sieleckiite, a new copper aluminium phosphate from Mt Oxide, Queensland, Australia
}

\author{
W. D. BIRCH \\ Department of Mineralogy and Petrology, Museum of Victoria, 285 Russell Street, Melbourne, \\ Victoria, 3000, Australia \\ AND \\ A. PRING \\ Department of Mineralogy, South Australian Museum, North Terrace, Adelaide, \\ South Australia, 5000, Australia
}

\begin{abstract}
Sieleckiite is a new copper aluminium phosphate discovered at the Mt Oxide Copper Mine, $150 \mathrm{~km}$ north of Mt Isa, Queensland, Australia. It occurs with variscite, turquoise, libethenite and minor pseudomalachite in a fracture in a boulder of quartzite and shale. Sieleckiite forms deep sky blue to royal blue spheres up to $0.5 \mathrm{~mm}$ in diameter, made up of fibrous radiating crystals between 20 and $100 \mu \mathrm{m}$ long and 1 to $2 \mu \mathrm{m}$ wide. The mineral has a very pale blue streak and a pearly lustre on uneven fracture surfaces. Hardness is about 3 and the measured density is $3.02 \mathrm{~g} \mathrm{~cm}^{-3}$. The average of nine electron microprobe analyses gave $\mathrm{CuO} 32.39, \mathrm{Al}_{2} \mathrm{O}_{3} 26.57, \mathrm{P}_{2} \mathrm{O}_{5} 19.42 \%$. Separate analyses gave $\mathrm{H}_{2} \mathrm{O} 18.1, \mathrm{CO}_{2} 1.6 \%$ (carbonate impurity). These data gave an empirical formula of $\mathrm{Cu}_{3.1} \mathrm{Al}_{4.0}\left(\mathrm{PO}_{4}\right)_{2.1}(\mathrm{OH})_{12} .1 .7 \mathrm{H}_{2} \mathrm{O}$, calculated on the basis of 22 oxygen atoms. The simplified formula is $\mathrm{Cu}_{3} \mathrm{Al}_{4}\left(\mathrm{PO}_{4}\right)_{2}(\mathrm{OH})_{12} \cdot 2 \mathrm{H}_{2} \mathrm{O}$. The strongest lines in the X-ray powder diffraction pattern are $\{d(I)(h k l)\} ; 9.12(50)(100), 5.06(100)(101)$, $3.852(100)(111), 3.276(30)(\overline{2} 20), 2.827(50)(\overline{1} 02,102), 2.460(50)(\overline{3} 21)$. These data were indexed on a triclinic cell with $a 9.41(8), b 7.56(5), c 5.95(6) \AA, \alpha 90.25(12)^{\circ}, \beta 91.27(12)^{\circ}, \gamma 104.02(7)^{\circ}$ and a volume of $410.8(5) \AA^{3}$. For $\mathrm{Z}=1$, the calculated density is $2.94 \mathrm{~g} \mathrm{~cm}^{-3}$. Optical properties could not be determined in full; the refractive indices are between 1.63 and 1.66 , pleochroism is very weak from colourless to very pale blue.

The mineral is named for the discoverer, Robert Sielecki (1958- ). Type specimens are preserved at the Museum of Victoria and the South Australian Museum. Sieleckiite was approved by the IMA Commission on New Minerals and Mineral Names prior to publication.
\end{abstract}

KEYWORDs: sieleckiite, new mineral, copper aluminium phosphate, Mt Oxide, Queensland, Australia.

\section{Introduction}

EARLY in 1986 specimens from the oxidized zone at the Mt Oxide copper mine, 150 kilometres north of Mt Isa, Queensland, Australia, were collected by a local geologist, Robert Sielecki. They were submitted to one of the authors (WDB) for identification. Most consisted of well crystallized variscite, turquoise and libethenite, but on four specimens, an unfamiliar mineral occurred as very small spheres of an intense blue colour. The X-ray diffraction pattern for the mineral could not be matched with any known species and its composition, a copper aluminium phosphate with hydroxyl groups, established it as a new mineral. The data and the name-after the finder, Robert Sielecki (1958 - ) -were approved by the Commission on New Minerals and Mineral Names in 1987 (87-23). Type specimens have been lodged in the Museum of Victoria and the South Australian Museum.

\section{Occurrence}

The new mineral occurred in a narrow fracture within a one-metre diameter quartzite-shale boulder found on a bench approximately 22 metres from the surface of the now abandoned open cut of the Mt Oxide mine. The associated minerals, well-crystallized variscite, turquoise and libethenite, with minor pseudomalachite, are relatively 
common in this part of the open cut, but further samples of the new mineral have not been encountered.

The Mt Oxide deposit is a small but rich copper orebody located $150 \mathrm{~km} \mathrm{NNW}$ of Mt Isa in Queensland, Australia (Lat. $19^{\circ} 29^{\prime}$ S, Long. $139^{\circ}$ $23^{\prime}$ E). The deposit occurs along a NE-trending shear zone within weakly metamorphosed sandy shales of the Lower Proterozoic Gunpowder Creek Formation (Carter et al., 1961).

The orebody was initially worked as an underground mine in the early 1900s. From 1926 to 1968 and again for a brief period in 1979, leaching techniques were used to extract the copper from both dump material and the walls of the open cut. The leaching process does not appear to have affected the area from which the sieleckiite-bearing boulder originated.

All production at $\mathrm{Mt}$ Oxide came from the zones of oxidation and secondary enrichment. Massive supergene chalcocite was the dominant copper mineral, with malachite and brochantite being the main oxidized species. Cuprite, tenorite, azurite, atacamite, turquoise and libethenite were present in lesser amounts. The primary ore was a massive pyrite body containing minor chalcopyrite and chalcocite.

\section{Physical and optical properties}

Sieleckiite typically occurs as individual spheres up to $0.5 \mathrm{~mm}$ in diameter. Its colour is a distinctive and attractive deep sky blue to royal blue (Royal

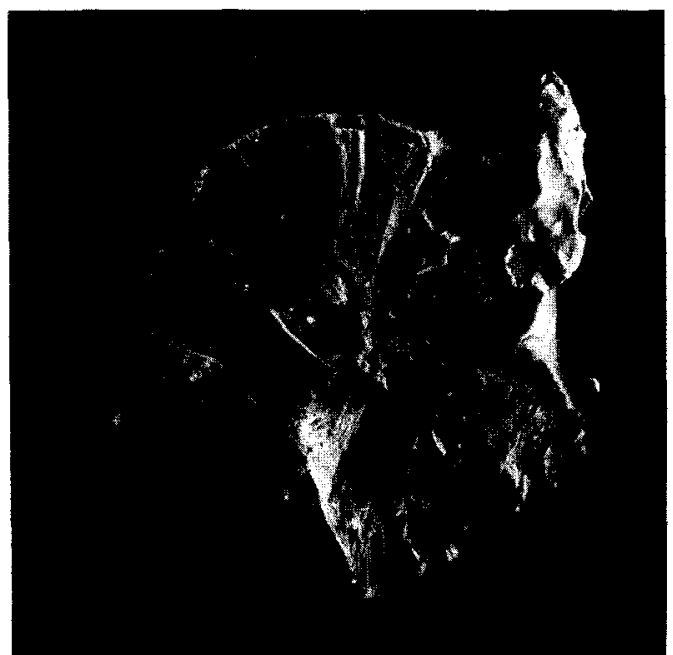

FIGis. 1 and 2. FIG. 1 (left). Scanning electron micrograph showing fibrous radiating internal structure of sieleckiite hemisphere $0.5 \mathrm{~mm}$ in diameter. FIG. 2 (right). Scanning electron micrograph showing a hemisphere of sieleckiite, $0.4 \mathrm{~mm}$ in diameter, on variscite crystals.

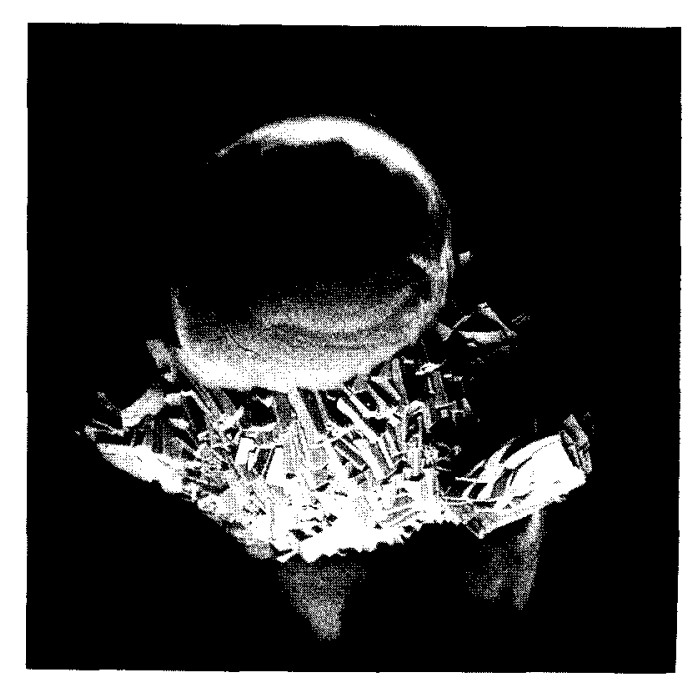

Horticultural Society, London, 109A). The spheres, which are slightly translucent, have a compact finely-fibrous radiating structure (Fig. 1) and a smooth outer surface with an overall pearly lustre (Fig. 2). The streak is pale blue.

Transmission electron microscopy revealed that individual crystals making up the radial aggregates were approximately $20-100 \mu \mathrm{m}$ long and $1-2 \mu \mathrm{m}$ in diameter. The density of the spheres was deter$\mathrm{CHCl}_{3}$ solution (mean of five determinations). The possibility of small fragments of turquoise and libethenite adhering to such small spheres could lead to some uncertainty in the measured density.

There is no detectable cleavage or twinning, the overall hardness is estimated to be about 3 on the Mohs scale, and the fracture is sub-conchoidal However these properties are mainly those of the aggregate, not the individual crystals. Fluorescence was not observed. The mineral is slowly soluble in cold dilute hydrochloric acid.

Due to the finely fibrous nature of sieleckiite and the minute single crystal size, complete optical data could not be obtained. Refractive indices are between 1.63 and 1.66 and the crystals are lengthslow. Pleochroism is weak, from colourless to very pale blue.

\section{X-ray crystallography}

$\mathrm{X}$-ray diffraction data for sieleckiite were recorded using an $80 \mathrm{~mm}$ diameter Guinier camera with monochromated $\mathrm{Cu}-K \alpha$ radiation and silicon mined as $3.02(2) \mathrm{g} \mathrm{cm}^{-3}$ by flotation in $\mathrm{CH}_{2} \mathrm{I}_{2} /$ 
internal standard. Initial attempts at indexing the pattern (Table 1) and refining the parameters of a triclinic unit cell were unable to provide a satisfactory match between measured and calculated density using the simplified formula. The difficulty was overcome by electron diffraction techniques. Small fractured crystal fragments were deposited on to holey carbon support films on $\mathrm{Cu}$ grids and coated with a thin film of gold for internal calibration. Diffraction patterns were obtained using a Philips EM400 Transmission Electron Microscope fitted with a double tilt goniometer. Crystal fragments were stable under the electron beam and this permitted several zones to be recorded from each fragment. With the aid of the calibrated electron diffraction patterns it was possible to index the powder data and refine the cell by least square methods using 23 reflections with $20<40^{\circ}$ (reflections above $40^{\circ}$ were too weak to measure accurately). The refinement yielded the following triclinic cell: $a=9.41(8), b=7.56(5), c=5.95(6) \AA$, $\alpha=90.25(12)^{\circ}, \beta=91.27(12)^{\circ}, \gamma=104.02(7)^{\circ}, \mathrm{V}=$ $410.8(5) \AA^{3}$. The axial ratios calculated from the unit cell parameters are $a: b: c=1.245: 1: 1.271$.

\begin{tabular}{|c|c|c|c|}
\hline dobs & $d_{\text {calc. }}$. & $I / I_{0}$ & $h k l$ \\
\hline 9.120 & \multirow{21}{*}{$\begin{array}{l}9.130 \\
5.949 \\
5.040 \\
4.931 \\
4.643 \\
3.851 \\
3.731 \\
3.668 \\
3.273 \\
3.160 \\
2.974 \\
2.877 \\
2.848 \\
2.808 \\
2.765 \\
2.683 \\
2.571 \\
2.520 \\
2.458 \\
2.413 \\
2.378 \\
2.347 \\
2.299 \\
2.238\end{array}$} & 50 & 100 \\
\hline 5.955 & & 10 & 001 \\
\hline 5.036 & & 100 & 101 \\
\hline 4.914 & & 5 & 101 \\
\hline 4.759 & & 20 & 011 \\
\hline 3.852 & & 100 & 111 \\
\hline 3.724 & & 10 & 120 \\
\hline 3.675 & & $3^{5}$ & $\frac{0}{2} 20$ \\
\hline 3.168 & & 10 & 121 \\
\hline $2.97 ?$ & & 10 & 002 \\
\hline 2.870 & & 10 & $\overline{2} 21$ \\
\hline 2.827 & & 50 & $\begin{array}{l}102 \\
102\end{array}$ \\
\hline 2.765 & & 5 & 121 \\
\hline 2.645 & & 15 & 320 \\
\hline $\begin{array}{l}2.570 \\
2.519\end{array}$ & & $\begin{array}{l}20 \\
10\end{array}$ & $\begin{array}{r}220 \\
130\end{array}$ \\
\hline 2.460 & & 50 & $\frac{1}{3} 21$ \\
\hline 2.413 & & 5 & 230 \\
\hline 2.378 & & 15 & 221 \\
\hline 2.348 & & 15 & 410 \\
\hline 2.309 & & 20 & 022 \\
\hline 2.230 & & 10 & 231 \\
\hline
\end{tabular}

\section{Chemistry}

Sieleckiite was analysed using a JEOL electron microprobe at $15 \mathrm{kV}$ and a specimen current of $0.020 \mu \mathrm{A}$. Standards used were pure metals $(\mathrm{Cu}$ and $\mathrm{Zn})$, synthetic corundum $(\mathrm{Al})$ and fluorapatite $(\mathrm{P})$ No other elements with atomic weight greater than 8 were detected by wavelength spectrometry. A total of nine microprobe analyses was obtained,

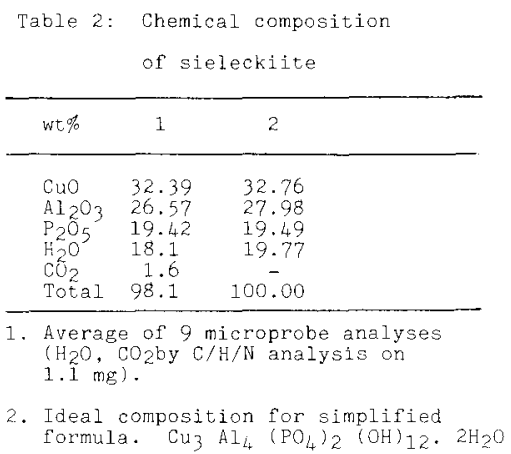

leading to the average composition shown in Table 2. In addition, a hydrogen content of $2.0 \mathrm{wt} . \%$ was determined on a $1.1 \mathrm{mg}$ sample using a Perkin Elmer 240 Automatic $\mathrm{C} / \mathrm{H} / \mathrm{N}$ Analyser. Based on 22 oxygen atoms, these data gave an empirical formula of

$$
\mathrm{Cu}_{3.11} \mathrm{Al}_{3.98}\left(\mathrm{PO}_{4}\right)_{2.09}(\mathrm{OH})_{12} \cdot 1.7 \mathrm{H}_{2} \mathrm{O}
$$

and a simplified formula of

$$
\mathrm{Cu}_{3} \mathrm{Al}_{4}\left(\mathrm{PO}_{4}\right)_{2}(\mathrm{OH})_{12} \cdot 2 \mathrm{H}_{2} \mathrm{O} \text {. }
$$

Carbon was detected during the $\mathrm{C}-\mathrm{H}-\mathrm{N}$ analysis, but the small amount (1.6 wt. \%) is thought to represent an unknown carbonate impurity, although no inclusions were visible in thin section. There is a possibility that the carbon is structural, perhaps as carbonate substituting for phosphate or hydroxyl (as may occur in apatite-group minerals; Le Geros and Le Geros, 1984), but without structural data and more material to work with it this problem cannot be resolved.

With the simplified formula and with $Z=1$ and $\mathrm{V}=410.8 \AA^{3}$, the calculated density is $2.94 \mathrm{~g} \mathrm{~cm}^{-3}$, which agrees quite well with the measured density of $3.02 \mathrm{~g} \mathrm{~cm}^{-3}$, given the slight uncertainty in the latter figure.

\section{Paragenesis}

The Mount Oxide assemblage is notable for the coexistence of three copper hydroxyl phosphates with turquoise; such an association is rare in nature as most other copper phosphates are generally unstable relative to turquoise (Nriagu, 1984). Based on textural evidence, a general sequence of crystallisation on sieleckiite-bearing specimens is

$$
\begin{aligned}
& \text { (variscite)-sieleckiite-libethenite- } \\
& \text { turquoise-pseudomalachite. }
\end{aligned}
$$

However on other specimens without sieleckiite there is no consistent sequence. The colourless variscite crystals are often relict, etched or hollow, 
and on one specimen have been pseudomorphed by crusts of drusy turquoise crystals. In a few localized areas on the specimens, sieleckiite appears to be altering to turquoise. Libethenite crystals are usually lustrous and appear to have been stable throughout the crystallization history. This suggests generally acid conditions prevailed for most of the period of crystallization but with more alkaline solutions prevailing during the final stages when small amounts of pseudomalachite formed.

All phases are very close to their ideal stoichiometry, indicating that their stabilities were not affected by the presence of other ions such as $\mathrm{Zn}$ and $\mathrm{Fe}$. Whether turquoise or sieleckiite crystallized at any one time may have depended on a delicate balance between the concentrations of $\mathrm{Cu}$ and $\mathrm{Al}$ in the precipitating solutions. For example, two equations relating variscite with either turquoise or sieleckiite may be written

$$
\begin{array}{r}
4\left[\mathrm{Al}\left(\mathrm{PO}_{4}\right) \cdot 2 \mathrm{H}_{2} \mathrm{O}\right]+\mathrm{Cu}(\mathrm{OH})_{2}+2 \mathrm{Al}(\mathrm{OH})_{3} \rightarrow \\
\mathrm{CuAl}_{6}\left(\mathrm{PO}_{4}\right)_{2}(\mathrm{OH})_{8} \cdot 5 \mathrm{H}_{2} \mathrm{O}+3 \mathrm{H}_{2} \mathrm{O}
\end{array}
$$

or

$$
\begin{array}{r}
2\left[\mathrm{Al}\left(\mathrm{PO}_{4}\right) \cdot 2 \mathrm{H}_{2} \mathrm{O}\right]+3 \mathrm{Cu}(\mathrm{OH})_{2}+2 \mathrm{Al}(\mathrm{OH})_{3} \rightarrow \\
\mathrm{Cu}_{3} \mathrm{Al}_{4}\left(\mathrm{PO}_{4}\right)_{2}(\mathrm{OH})_{12} \cdot 2 \mathrm{H}_{2} \mathrm{O}+2 \mathrm{H}_{2} \mathrm{O} .
\end{array}
$$

Both equations would explain the observed dissolution of some of the variscite, and the first would account for the pseudomorphing by turquoise. The high concentrations of phosphate were probably derived from the surrounding sediments.

There are only two other hydrated copper aluminium phosphates with hydroxyl groupsturquoise and zapatalite - which have been recor- ded as occurring naturally, although an unknown copper aluminium phosphate which resembles sieleckiite was recently referred to from Cornwall by Weiss (1987). Sieleckiite is close to zapatalite (Williams, 1972) in terms of its chemical formula, but the X-ray diffraction patterns of the two minerals are distinctly different.

\section{Acknowledgements}

The authors wish to thank Dr D. J. M. Bevan (Flinders University, South Australia) for assistance in obtaining the X-ray powder diffraction data. Miss E. M. McBriar (University of Adelaide) provided help with measurement of the optical properties of sieleckiite. The microprobe analyses were obtained in the Geology Department, University of Melbourne, with the assistance of $\mathrm{Mr}$ D. K. B. Sewell.

\section{References}

Carter, E. K., Brooks, J. H., and Walker, K. R. (1961) Bureau of Mineral Resources, Geology and Geophysics, Bulletin 51.

Le Geros, R. Z. and Le Geros, J. P. (1984) Phosphate minerals in human tissues. In Phosphate Minerals (Nriagu, J. O. and Moore, P. B., eds.). Springer-Verlag, Berlin, 351-85.

Nriagu, J. O. (1984) Formation and Stability of Base Metal Phosphates in Soils and Sediments. Ibid. 318-29.

Weiss, S. (1987) Der Bergbaubezirk Callington Calstock. Lapis, 3, $21-9$.

Williams, S. A. (1972) Mineral. Mag. 38, 541-4.

[Manuscript received 24 September 1987;

revised 24 November 1987] 